\title{
Omar Hassaine
}

Address (es): Prof. Omar Hassaine,

Oran1 University, Faculty of Sciences of Nature and Life, Department of Biotechnology, Laboratoire de Biologie des Microorganismes et Biotechnologie, BP. 1524 El

M`Naouer, 31000 - Oran, Algeria.

Corresponding author: omar.hassaine@ hotmail.com

In this work, the individual and interactive effects of temperature and $\mathrm{pH}$ on the proteolytic activity of Lactococcus lactis LCL strain in milk were studied by quadratic Response Surface Methodology. The effects of the selected variables have been analysed using a Central Composite Design and the maximum response (proteolysis rate) under the optimum values of variables and of a satisfactory fit model was realized. The mathematical relationship of the proteolytic activity on the two significant independent variables can be approximated by a nonlinear polynomial model. Predicted values were found to be in a good agreement with experimental values $\left(R^{2}=\right.$ 0.937) demonstrating the good significance of the model. The result of optimization predicted by the model has shown that the maximal result for the proteolysis rate revolved around of $43.7 \pm 1.4 \%$ at the optimal condition $\left(30^{\circ} \mathrm{C}\right.$ and $\left.\mathrm{pH} 7\right)$.

Keywords: Response Surface Methodology, Lactococcus lactis, proteolytic activity, Temperature, $\mathrm{pH}$

\section{INTRODUCTION}

Lactic acid bacteria belong to a well-known group of bacteria that presents a high biotechnological potential, have been used as mixtures of selected bacteria as starter or adjunct cultures in food production, especially in fermented dairy products, in the milk, vegetables, ensilage and meat industries (González et al. 2010; Konings et al. 2000; Ni et al. 2015). Indeed, these bacteria have been used by mankind for centuries due to their ability to produce desirable sensory characteristics, to improve digestibility and to inhibit pathogenic and spoilage microorganisms

The benefits of lactic acid bacteria are well recognized due to their health and nutritional effects of the live micro-organisms, probiotics or indirect effects of the metabolites with health-promoting characteristics (Hayes et al. 2007). These micro-organisms are capable to produce several substances such as organic acids, diacetyl, hydrogen peroxide, bacteriocins and bioactive peptides, which play an important role in food fermentation and preservation (Moraes et al. 2010; Perez et al. 2014). lactic acid bacteria exhibit diverse sensory properties; contribute to the development of flavor, color, and texture; and improve the safety, stability, and shelf life of food products (Frece $\boldsymbol{e t}$ al. 2009). An appropriate selection of strains as starter could improve the typical characteristics of fermented dairy products (Casaburi et al. 2016). Therefore, study of the technological and biochemical properties of the strains involved in this process is fundamental to obtain products of the expected quality.

Lactococcus lactis is one of the most economically important specie of lactic acid bacteria, widely used in the manufacture of cheeses, and fermented milk, this bacteria has the ability to reduce bitterness and give characteristic flavor to cheese during the ripening, which makes her, the important component of starter cultures for the dairy industry (Hugenholtz and Kleerebezem 1999; Settanni and Moschetti 2010; Smit et al. 2005; Steele et al. 2013).

Consumer interest in functional food has motivated researchers to a growing interest to these solicitations by proposing new alternatives, like to the use of lactic acid bacteria as protective cultures, and by exploiting their proteolytic activities for the generation of bioactive compounds in dairy products (Liu et al. 2010; Matar et al. 2003; Vinderola et al. 2007; Wakai and Yamamoto 2012).

Milk provides most lactic acid bacteria with excellent substrates for growth; however, the concentration in small peptides and free amino acids is low. To grow at a high cellular density, lactic acid bacteria need to overcome their auxotrophy for certain amino acids by hydrolyzing milk caseins to benefit from an amino acid source. The breakdown of milk proteins (proteolysis) plays an important role in the production of different types of metabolites in fermented food products (Liu $\boldsymbol{e t}$ al. 2010; Shihata and Shah 2000). This ability can also cause the release of a wide range of peptides, not only by contributing to the development of characteristic flavors in fermented products but also by exercising different bioactivities.

Milk proteins may be a source of functional ingredients, especially the caseins, as the main precursors of biologically active peptides, which are encrypted in their primary structure, who cannot modulate physiology of the consumer only after their proteolytic release (Bhat and Bhat 2011; Silva and Malcata 2005).
Depending on size and amino acid sequence, milk-derived peptides may exert a number of different activities in vitro and/or in vivo, such as immuno-modulation, antitumor action, hypocholesteremic effect, antimicrobial, mineral-binding, opioid agonists, antioxidant, antihypertensive and peptidase inhibition activities (Donkor et al. 2007; Fitzgerald and Murray 2006; Liu et al. 2016; Mills et al. 2011). The proteolytic systems from lactic acid bacteria are the main route to generate bioactive peptides during milk fermentation and cheese ripening (Gobbetti $\boldsymbol{e t}$ al. 2004). The lactic acid bacteria posses' variable patterns of proteinases, peptidases and peptide transport systems enable them to use milk casein as a source of amino acids and nitrogen and release of bioactive peptides in milk in a species- and strainspecific manner (Liu et al. 2010). The Cell-envelope proteases break down proteins into peptides of about 5-30 amino acids that are carried into the cell and further hydrolysed by endopeptidases into smaller peptides and amino acids for microbial protein synthesis. The proteolytic systems of lactic acid bacteria have been studied extensively, particularly that of Lactococcus lactis and several lactobacilli species, as well as that of Streptococcus thermophilus and Lactobacillus delbrueckii subsp. bulgaricus (Cao et al. 2019; Do Carmo et al. 2011; Griffiths and Tellez 2013; Liu et al. 2010; Rodríguez-Serrano et al. 2018). In the same way the approach of a metabolic engineering of lactic acid bacteria, concerning proteolysis has been attempted in numerous occasions at a physiological and genetic level to improve flavor development in cheese (Hugenholtz and Kleerebezem 1999; Smit et al. 2005; Steele et al. 2013). Considering of this interest activity, several ways to obtain these bioactive peptides are conceivable, either by their addition to food after their in vitro release from milk proteins by the action of proteases used in the food industry, or by releasing them directly, by the action of the proteolytic system of bacteria commonly used in the manufacture of fermented dairy products (Fitzgerald and Murray 2006; Korhonen and Pihlanto 2006). However, this approach of production in a targeted manner of certain bioactive peptides during the fermentation process seems to be difficult to control (Paul and Somkuti 2009; Paul and Somkuti 2010; Somkuti and Paul 2010). Indeed, it depends largely on the choice of the bacteria to use, and of course, of the control of the optimized parameters governing its proteolytic activity, with a view to a possible production of fermented dairy products containing bioactive peptides.

The application of proteolytic food-grade lactic acid bacteria has been considered as a new strategy for producing novel functional food rich in bioactive peptides (Hayes et al. 2007), this is the case for example from the antioxidant peptides extracted recently from fermented meat products, as a substitute of a synthetic antioxidant in the food system (Xing et al. 2018). Hence, the strategy of a guidance of the starter cultures towards higher proteolytic activity by optimization could be a good alternative for the production of fermented dairy products, targeting the development of characteristic flavors, in parallel to an increase in the pool of released peptides, very likely containing a fraction of biologically active peptides. Therefore, in this order of idea, an intensification of this activity stands out as being as a good alternative by adopting a statistical optimization approach, which seems to be a judicious and interesting methodology, widely used in many areas of biotechnology. 
As an alternative to the one-factor-at-time, classical experimental approach, the experimental design method was used, in which the levels of all factors were varied at same time for each experiment. The advantages included a reduction in the number of trials, the ability to cover a large number of factors, the detection of interactions between factors, the detection of optima, a higher precision of the response data, and the empirical modeling of data (Goupy 1988). This optimization approach for any industrial interest response is based on the control, design and analysis of the developed mathematical models, formulated with parameters of clear biological significance and statistically consistent which can be easily implemented to miscellaneous applications. This strategy of optimization is a statistical Design of Experiment (DOE) method, which systematically evaluates more than one independent factor at a time. The Response Surface Methodology (RSM) is commonly used to explore nonlinear relationships between studied factors and the dependent variables (Box and Wilson 1951; Goupy 1988). Compared with conventional methods, the RSM, is a time and labor saving method, which also reveals the interaction between the components of a reacted medium and seek the physical and chemical optimum levels (Ghadge and Raheman 2006; Tang et al. 2004). Central composite design (CCD) was the most used response surface design method (Box and Wilson 1951), is an experimental strategy for seeking the optimum conditions for a multivariable system and it is an efficient technique for optimization. It also provides information about optimal values of these factors to determine the expected largest (or smallest) value for the dependent variable of interest. This methodology includes factorial design and regression analysis (Box and Wilson 1951; Goupy 1988; Mangayil et al. 2015; Zhang et al. 2011).

The use of indigenous strains isolated from Algerian terroir products, displaying desirable technological properties, is part of one of the components of our country's overall economic strategy. In this setting, the Latococcus lactis LCL strain was selected beforehand in relation to its numerous interesting technological properties (Hassaine et al. 2014; Ras El Gherab et al. 2019), with the ambition of intensifying its metabolic activities of interest with a view to use on a large scale, in particular for that of proteolytic activity in cow's milk at firstly, and subsequently, in other milks, so as camel milk for example.

Gathering the conditions governing the intensification of this activity for this strain, is an indispensable approach, which necessarily leads us to an optimization, and therefore to propose this alternative, by using a statistical optimization approach, which seems to be a judicious methodology and interesting, which has a proven track record in many areas of biotechnology. In the present study, the RSM methodology has been applied in order to seek the optimum levels for highest proteolytic activity in milk for Lactococcus lactis LCL strain. The Central Composite design (CCD) has been performed to evaluate the effect of physicochemical factors such as $\mathrm{pH}$ and temperature on the proteolytic activity of Lactococcus lactis LCL strain, by interacting them together at the same time, and by examining the linear, quadratic and their possible interaction effect. The coefficients of quadratic mathematical model were also determined.

\section{MATERIAL AND METHODS}

\section{Bacterial strain and culture conditions}

The bacterial strain Lactococcus lactis LCL, used throughout this investigation was obtained from the culture collection of "Laboratoire de Biologie des Microorganismes et Biotechnologie" at Oran 1 University (Algeria). This strain was routinely maintained at $4{ }^{\circ} \mathrm{C}$ after growth for $24 \mathrm{~h}$ at $30^{\circ} \mathrm{C}$ in $\mathrm{M} 17$ medium (Terzaghi and Sandine 1975). For longer-term maintenance, stock culture was stored at $-20^{\circ} \mathrm{C}$ in $\mathrm{M} 17$ broth with $20 \%$ (v/v) glycerol. As required, this culture was thawed and revitalized in $\mathrm{M} 17$ broth at $30^{\circ} \mathrm{C}$ for $24 \mathrm{~h}$ by two transfers.

\section{Electrophoretic analysis of skim milk casein hydrolysis}

The proteolytic activity was evaluated using the protocol described by (Tsakalidou et al. 1999) with some adaptations by using the whole cell suspension as source of enzyme and skim milk as substrate. The effect simultaneously of two parameters (Temperature and $\mathrm{pH}$ ) on this activity was investigated using Response Surface Methodology described under mentioned.

\section{Sample preparations}

Bacterial cells of a fresh culture in M17 medium were harvested by centrifugation at exponential phase and washed three time in cold buffer solution $(100 \mathrm{mM}$ $\mathrm{NaH}_{2} \mathrm{PO}_{4}-\mathrm{Na}_{2} \mathrm{HPO}_{4}, \mathrm{pH} 7.0$ ) containing $30 \mathrm{mM}$ of $\mathrm{CaCl}_{2}$, and concentrated 10 fold in various buffers solutions containing $1 \mathrm{mM}$ of $\mathrm{CaCl}_{2}$ according the $\mathrm{pH}$ under consideration. For the range $\mathrm{pH}$ values 5 to 6 in $100 \mathrm{mM}$ acetate buffer; $\mathrm{pH}=7$ in $100 \mathrm{mM}$ phosphate buffer and $\mathrm{pH} 8$ to 9 in $100 \mathrm{mM}$ Tris- $\mathrm{HCl}$ buffer. At $2 \mathrm{ml}$ of this bacterial suspension, $1 \mathrm{ml}$ of sterile skim milk "Candia Silhouette" are added and incubated at appropriate $\mathrm{pH}$ and temperatures according the designed experiment described in the CCD table (Table 1). The essays were performed in triplicate.

For the whole-cell/substrate incubation, the mixture was stopped by centrifugation (12000 $\mathrm{g}$ for $5 \mathrm{~min}$ ) and the aliquots were taken at $0 \mathrm{~h}$ and $24 \mathrm{~h}$ of incubation and were frozen at $-20^{\circ} \mathrm{C}$ in order to stop the proteolysis reaction. One hundred and fifty micro-litter $(150 \mu \mathrm{l})$ of this aliquots were diluted into $32 \mu \mathrm{l}$ of solubilization buffer [ $2 \mathrm{ml}$ of $200 \mathrm{~g} / \mathrm{L}$ sodium dodecyl sulphate (SDS), $2.5 \mathrm{ml}$ of $25 \mathrm{mM}$ Tris-192 $\mathrm{mM}$ glycine buffer, $\mathrm{pH} 8.3$, and $4.5 \mathrm{ml}$ of distilled water mixed extemporaneously with $1 \mathrm{ml}$ of $\beta$-mercaptoethanol ]. The mixtures were incubated at $80^{\circ} \mathrm{C}$ for $10 \mathrm{~min}$ and centrifuged $(9000 \mathrm{~g}, 10 \mathrm{~min})$. An aliquot $(50 \mu \mathrm{l})$ of the supernatants was mixed with $10 \mu \mathrm{l}$ of $30 \%$ glycerol containing $0.004 \mathrm{~g} / \mathrm{L}$ bromophenol blue and heated at $100{ }^{\circ} \mathrm{C}$ for 2 min before electrophoresis.

\section{Electrophoretic analysis}

SDS-polyacrylamide gel electrophoresis (SDS-PAGE) was performed with the buffer system described by (Laemmli 1970) using 15\% acrylamide. Gels were run at $25 \mathrm{~mA}$ until bromphenol blue tracking dye had moved to $0.5 \mathrm{~cm}$ from the bottom of the gel. Proteins were stained with Coomassie Brilliant Blue R250.

\section{Design of experiments (DOE) and statistical analysis}

Response Surface Methodology (RSM) is a collection of mathematical and statistical techniques that are useful for the modeling and analysis of problems in which the response of interest is influenced by several variables and whose objective is to optimize this response. All statistical analysis was carried out using the STATISTICA v.7.0 software package (StatSoft, USA) for experimental design, data analysis and quadratic model building. In this study, the proteolytic activity of Lactococcus lactis LCL strain was optimized using one-way analysis of variance.

\section{Central Composite Design (CCD)}

The statistically-based optimization using central composite design (CCD) was carried out under response surface methodology (RSM), which is widely used in experiments where the main interest is in modeling the relationship between a number of quantitative factors and one or more response variables, then locating the combination of the factor levels that yields the best response. (Box and Draper 1987).

In this study, two operating factors were chosen as independent variables, respectively named, Temperature and $\mathrm{pH}$. The STATISTICA software was used to perform the regression analysis and graphical analysis of the data obtained. A central composite design (CCD) with two independent variables was used and each variable was studied at five levels $(-\alpha,-1,0,+1$, and $+\alpha)$.

This system (CCD for 2 factors) is composed of four corners of the square represent the factorial (+/- 1) design points, four-star points represent the axial (+/$\alpha$ ) design points and four replicates at the center points leading to 12 sets of experiments have been used to the optimization of the proteolytic activity of Lactococcus lactis LCL strain. The variables were coded according to the following equation (Equation 1).

$x_{i}=\left(X_{1}-X_{0}\right) / \Delta X \quad i=1,2, \ldots \ldots \ldots, k(1)$

where, $x_{i}$ is the coded value of an independent variable, $X_{1}$ is the real value of an independent variable, $X_{0}$ the value of $X_{l}$ at the center point, and $\Delta X$ the step change. A set of 12 experiments were performed. The minimum and maximum ranges of variables were used, and the full experimental design with respect to their coded values is shown in Table 1. The second-order polynomial equation comprised linear, quadratic and interaction terms in the form shown below (Equation. 2).

$Y=\beta_{0}+\sum_{i=1}^{k} \beta_{i} x_{i}+\sum_{i=1}^{k} \beta_{i i} x_{i}^{2} \sum_{i j=1}^{k} \beta_{i j} x_{i} x_{j}$

where, $Y$ is the predicted response, $x_{i}$ and $x_{j}$ are coded independent variable, $\beta_{0}$ the intercept term, $\beta_{i}$ is the linear coefficient, $\beta_{i i}$ is the quadratic coefficient and $\beta_{i j}$ is the interaction coefficient and $k$ is number of factors.

The analysis of variance (ANOVA) was performed in order to evaluate the statistical significance of the model. The response surface graphs were plotted in order to better understand the interaction between different variables and to 
determine their optimum levels. Statistical significance of the above model equation was determined by Fisher's test value, and the proportion of variance explained by the model was given by the multiple coefficient of determination, $R$ squared $\left(R^{2}\right)$ value.

\section{Data Analysis and software}

For the obtained gels, the densitometric analysis was carried out with scanning a gels with a desktop scanner (EPSON Perfection V370) using a grey scale mode at a greater and saving this file in a TIFF format. The analysis of the obtained digitized gels was carried out using ImageJ free software offered by the (NIH) National Institutes of Health, Baltimore, USA (http://rsbweb.nih.gov/ij/ ). Each obtained peak has been selected and evaluated for its area and the corresponding numerical value was used for further analysis. The results of proteolytic activity ware expressed as the percentage, as described to the following Equation (Equation $3)$.

Proteolysis rate $=\left[\left(\mathrm{AP}_{\mathrm{t} 0}-\mathrm{AP}_{\mathrm{t} 24}\right) / \mathrm{AP}_{\mathrm{t} 0}\right] \times 100$,

With AP is the Area of Peak obtained at 0 or $24 \mathrm{~h}$ of incubation.
STATISTICA v.7.0 software package (StatSoft, USA) was used for the experimental design matrix, data analysis and quadratic model building. The desirability charts and response surface representation as well generated graphically by the same software for determined the optimum levels of variables and more understand their interactions.

\section{Experimental validation of the optimized conditions}

In order to validate the optimization conditions for a desired level of response (proteolysis), three tests were carried out at the optimal values of variables to confirm the results of the response surface analysis.

\section{RESULTS AND DISCUSSION}

The effects of two variables on the proteolytic activity were studied. Table 1 displays the design matrix of the variables in coded units and real values with the respective results obtained from the central composite design regarding the studied variables; the temperature of incubation $\left(\mathrm{X}_{1}\right)$, and $\mathrm{pH}\left(\mathrm{X}_{2}\right)$ using the Lactococcus lactis LCL strain.

Table 1 Box-Wilson Central Composite Design (CCD) matrix with two variables used for the optimization of proteolytic activity of Lactococcus lactis LCL strain.

\begin{tabular}{lcccccc}
\hline \multirow{2}{*}{ Runs } & \multicolumn{2}{c}{ Coded level of variables } & \multicolumn{2}{c}{ Actual level of variables } & \multicolumn{2}{c}{ Proteolysis Rate $(\%)$} \\
\cline { 2 - 6 } & $\mathrm{X} 1$ & $\mathrm{X} 2$ & Temperature $\left({ }^{\circ} \mathrm{C}\right)$ & $\mathrm{pH}$ & $\begin{array}{c}\text { Observed } \\
\text { Values }\end{array}$ & $\begin{array}{c}\text { Predicted } \\
\text { Values }\end{array}$ \\
\hline 1 & -1 & -1 & 15 & 6 & 3,95 & 6,37 \\
2 & +1 & 45 & 6 & 13,39 & 10,44 \\
3 & -1 & +1 & 15 & 8 & 18,81 & 17,08 \\
4 & +1 & 0 & 35 & 8 & 17,88 & 10,78 \\
5 & 0 & 0 & 30 & 7 & 41,39 & 42,67 \\
6 & 0 & 0 & 8,7 & 7 & 45,35 & 42,67 \\
7 & $-1,42(-\alpha)$ & 0 & 31,3 & 7 & 20,75 & 19,29 \\
8 & $1,42(+\alpha)$ & $-1,42(-\alpha)$ & 30 & 5,58 & 11,61 & 17,71 \\
9 & 0 & $1,42(+\alpha)$ & 30 & 8,42 & 0 & $-0,60$ \\
10 & 0 & 0 & 30 & 7 & 40,47 & 4,24 \\
11 & 0 & 0 & 30 & 7 & 43,41 & 42,67 \\
12 & 0 & & & & & 42,67 \\
\hline
\end{tabular}

The highest proteolytic activity achieved in the verification experiment was 45.35 $\%$ (as seen in run 6), around the center points, at $30^{\circ} \mathrm{C}$ and $\mathrm{pH} 7$. The results of the second-order response surface model for the proteolytic activity in the form of analysis of variance (ANOVA) were given in Table (2) and (3) respectively.

The application of multiple regression analysis method yielded that the proteolytic activity was an empirical function of tested variables in coded unit as shown in following equation (Equation 4).

$Y=42.6740-0.5563 X_{1}+2,7624 X_{2}-11.9887 X_{1}^{2}-19.5169 X_{2}^{2}-2.5925 X_{1} X_{2}$ (4)
Where $\mathrm{Y}$ is the predicted response (proteolysis rate) and $\mathrm{X}_{1}, \mathrm{X}_{2}$, are the coded values for the temperature of incubation and $\mathrm{pH}$, respectively. The quadratic model in equation (4) contains five terms, two linear terms, two quadratic terms and one factorial interaction.

The model coefficients were estimated by multiple linear regressions and the significance of each model parameter was determined by Student's $t$-distribution and $P$-values, which are listed in Table 2 . The $P$-value was used as a tool for checking the significance of each coefficient. A larger magnitude of the $t$-test and smaller $P$-value denote greater significance of the corresponding coefficient.

Table 2 Model coefficient estimated by multiplies linear regression

\begin{tabular}{lcccc}
\hline Factor & Standard Error & Coefficient & $\begin{array}{c}\text { Computed } \\
t \text {-value }\end{array}$ & $p$-value \\
\hline Intercept. & 2,4942 & 42,6740 & 17,1086 & $0,000003^{*}$ \\
$\left(\mathrm{X}_{1}\right)$ Temperature (L) & 1,7601 & $-0,5563$ & $-0,3160$ & 0,762661 \\
$\left(\mathrm{X}_{1}^{2}\right)$ Temperature (Q) & 1,9606 & $-11,9887$ & $-6,1145$ & $0,000873 *$ \\
$\left(\mathrm{X}_{2}\right) \mathrm{pH}(\mathrm{L})$ & 1,7601 & 2,7624 & 1,5694 & 0,167602 \\
$\left(\mathrm{X}_{2}^{2}\right) \mathrm{pH}(\mathrm{Q})$ & 1,9606 & $-19,5169$ & $-9,9542$ & $0,000059 *$ \\
$\left(\mathrm{X}_{1}\right)$ Temperature $(\mathrm{L})$ by $\left(\mathrm{X}_{2}\right) \mathrm{pH}(\mathrm{L})$ & 2,4943 & $-2,5925$ & $-1,0393$ & 0,338699 \\
\hline
\end{tabular}

*: Statistical significance

In the present work, the result show that the second-order (quadratic) effect of variables $\mathrm{X}_{1}$ (Temperature) and $\mathrm{X}_{2}(\mathrm{pH})$, had a highly significant effect on the response (proteolytic activity), based on $P$-values lower than 0.001 ( $P$-value < 0.001 ), but at negatives coefficients. The negative signs of these terms bring about a scaling down of this response when their levels increase in the system. While the linear effect of temperature $\left(\mathrm{X}_{1}\right)$ and $\mathrm{pH}\left(\mathrm{X}_{2}\right)$ as well as their interaction terms $\left(\mathrm{X}_{1} \mathrm{X}_{2}\right)$ were not significant in the range of this study, considering their $P$-value. The non-significant coefficients were discarded from the Eq. (4) leading to the following equation (5), representing the reduced fitted model.
$\mathrm{Y}_{f}=42.6740-11.9887 \mathrm{X}_{1}^{2}-19.5169 \mathrm{X}_{2}^{2}$

In Table 3, the results of the analysis of variance (ANOVA) are summarized to test the soundness of the model. The ANOVA is a statistical technique subdivides the total variation in a set of data into component parts associated with specific sources of variation for testing hypotheses on the parameters of the model (Francesc and Julia 2014; Tripathi et al. 2009). Results were assessed with various descriptive statistics such as the $P$-value, $F$-value, and the degree of freedom, as well as the determination coefficient $\left(R^{2}\right)$. Likewise, each coefficient of $\mathrm{Eq}(5)$ was determined by Fisher's $F$-test and values of probability ( $P$-Value). The ANOVA of the 
quadratic regression model indicated that the model was highly significant, as the $F$-value (Fisher's $F$-test) for the model was 17.92 with a very low probability value $(P$-value $=0.0015)$. This analysis suggested that all the independent variables studied had a significant effect on proteolytic activity of the Lactococcus lactis LCL strain. As shown in Table 3, a small probability value indicates that the model was highly significant and could be used to predict the response function accurately.

Table 3 Analyze of variance (ANOVA) for the second-order polynomial model.

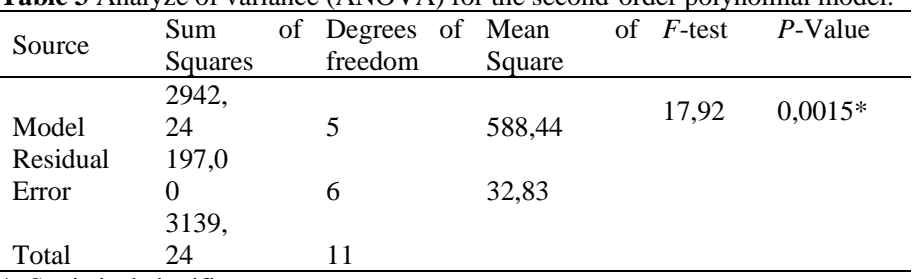

*: Statistical significance

$R^{2}=0,937 ;$ adj $-R^{2}=0,884 ; R=0,968$ and adj- $R=0,940$.

Goodness-of-fit for the model was also evaluated by coefficients of determination $R^{2}$ (correlation coefficient) and adjusted coefficients of determination adj- $R^{2}$. The ANOVA results showed that the model was significant with a coefficient of determination $\left(R^{2}\right)$ of 0.937 . In this case, the $R^{2}$-value for Equation (5) indicating that the model could explain $93.7 \%$ of the variability in the response, while only $6.3 \%$ of the variation could not be explained. It is widely admitted that a regression model with an $R^{2}$ - value greater than 0.9 is considered as having a very high correlation (Rao et al. 2006).

The value of the adjusted determination coefficient (adjusted $R^{2}=0.884$ ) was also high, demonstrating the good significance of the model and indicating a good agreement between the experimental values and those predicted.

This correlation is also confirmed by the plot of predicted versus experimental values of proteolytic activity, shown in Figure (1), as all points cluster around the diagonal line, demonstrating that no significant violations of the model were found.

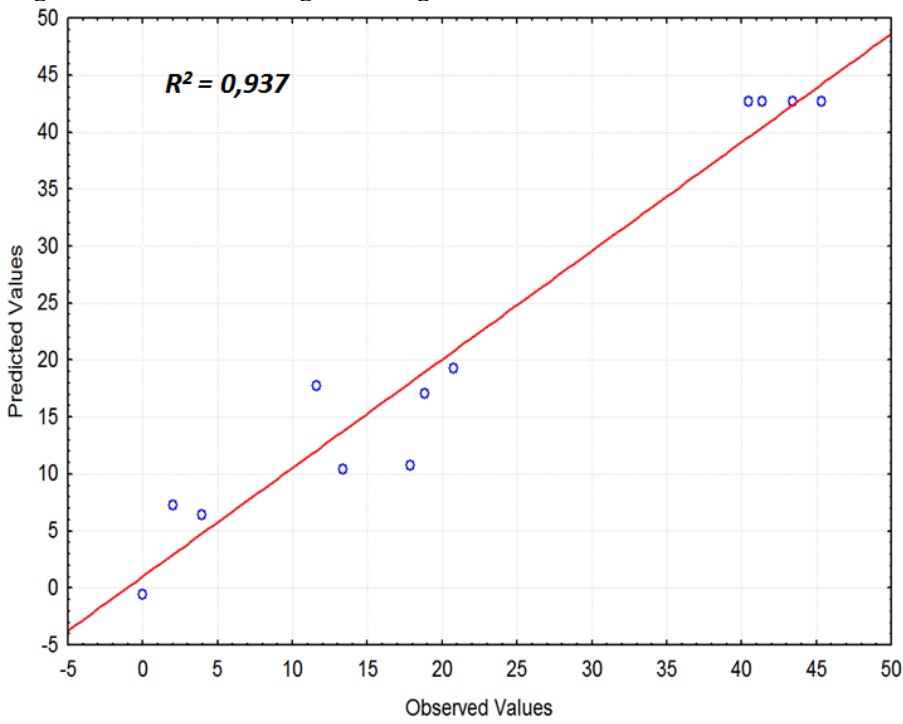

Figure 1 Relation between experimental (observed) and predicted value of the proteolytic activity of Lactococcus lactis LCL strain

The three-dimensional (3D) response surface is generally the graphic representation of the regression equation for the optimization of reaction conditions and is the most useful approach in revealing the conditions of the reaction system. This representation provides a visual interpretation of the interaction between two variables, facilitates the determination of optimum experimental conditions, and locates the optimal level of each variable for maximal response (Figure 2). The response surface plotted for response (proteolysis rate) represents the combinations of two test variables at one time. The convex response surfaces suggest that there are well-defined optimal variables. If the surfaces are rather symmetrical and flat near the optimum, the optimized values may not vary widely from the single variable conditions (Rao et al. 2006).

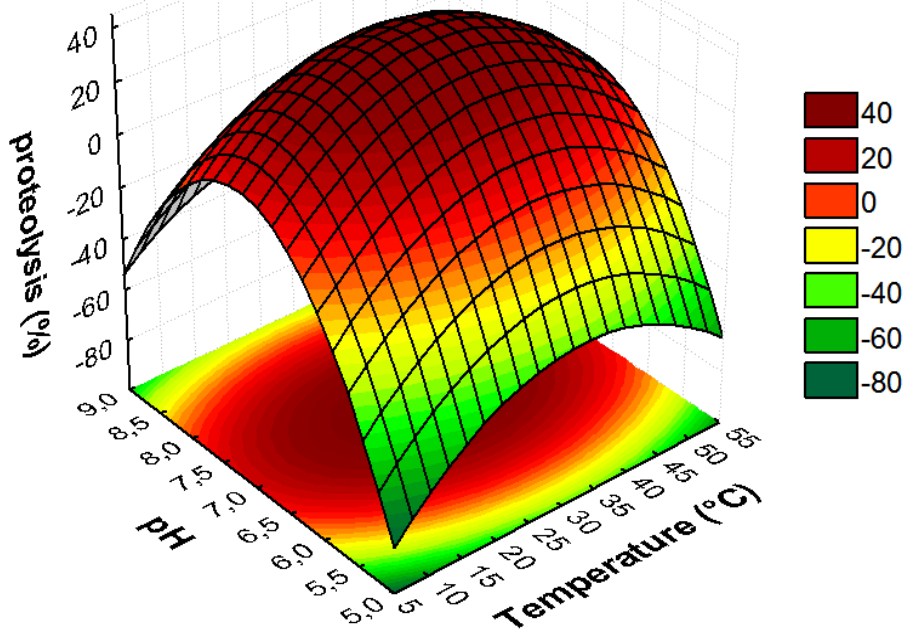

Figure 2 Response surface plot showing the effect of $\mathrm{pH}$ and Temperature on the proteolytic activity of Lactococcus lactis LCL strain.

The primary function of starter bacteria is to produce acid during the fermentation process; however, they also contribute to cheese ripening where their enzymes are involved in proteolysis and conversion of amino acids into flavour compounds such as aldehydes, alcohols and esters (Settanni and Moschetti 2010). At the same time, a growing interest has been focused in recent years on proteolysis products as factors of human health benefit (Hayes et al. 2007; Hebert et al. 2008; Hebert et al. 2010). Starter bacteria encountered most often in these many domains are members of the genera of Lactococcus in the first place, followed by Lactobacillus, Streptococcus, Leuconostoc and Enterococcus. They recently gained a growing interest for their use as protective cultures or for their proteolytic activities (Tulini et al. 2016).

Like other lactic acid bacteria, Lactococcus lactis is auxotrophic for several amino acids and is, therefore, dependent on the use of exogenous nitrogen sources for optimal growth (Hebert et al. 2000; Sadat-Mekmene $\boldsymbol{e t}$ al. 2011), so rapid growth in milk that contain only small amounts of amino acids and short peptides relies on a complex proteolytic enzyme system to obtain essential amino acids from caseins during growth in milk.

The importance and detailed analysis of the proteolytic enzyme system in dairy lactic acid bacteria has been discussed in a number of papers over the last several years (Do Carmo et al. 2011; Liu et al. 2010), most notably Lactococcus lactis, has shown that enzymes involved in the release of essential amino acids from large proteins such as casein can be loosely divided into 3 major categories: (1) an extracellular, cell envelope-associated proteinase (CEP) that hydrolyzes casein into oligopeptides; (2) specialized transport systems to take up those oligopeptides, as well as di- and tripeptides, and free amino acids that may be present in the medium; and (3) intracellular endopeptidases and exopeptidases, including many that are specific for proline-containing peptides, which degrade internalized peptides into di- and oligopeptides and free amino acids (Christensen et al. 1999; Savijoki et al. 2006).

Although the biological role of the proteolytic enzyme system is directed toward cellular growth needs, the actions of these enzymes in cheese and fermented foods has important practical consequences on the development of flavor and texture of fermented products (Law and Haandrikman 1997) and can promote human health through the release of bioactive peptides during milk fermentation (Hayes et al. 2007; Hebert et al. 2008; Hebert et al. 2010). For these reasons, the relationship between proteolytic enzyme activity and dairy foods quality has been a focal point of dairy research for decades. Proteolytic systems from lactic acid bacteria are the main route to generate bioactive peptides during milk fermentation and cheese ripening (Gobbetti et al. 2004). lactic acid bacteria possesses variable patterns of proteinases, peptidases and peptide transport systems which affect release and intake of bioactive peptides in milk in a species- and strain-specific manner (Liu et al. 2010).

In order to taking advantage of the powerful proteolytic system of this bacterium, because an increase of proteolytic activity has a direct consequence on the rapid growth of lactic acid bacteria, which is a technologically important for the 
development of the organoleptic properties of fermented milk products. In this same sense, considering the potential beneficial health effects of the peptides released by Lactococcus lactis from milk proteins, a mastery of these processes, inevitably leads us to an adjustment and control of many physicochemical parameters, including water content, salt concentration, temperature and $\mathrm{pH}$, during fermentation and also during the ripening of cheeses. The extent of more variation in these parameters is influenced by the cheese making process. The optimum $\mathrm{pH}$ for the growth of most common bacteria is around neutral and growth is often poor at $\mathrm{pH}$ values $<5.0$. The real inhibitor is thought to be the undissociated form of the organic acid, the principal organic acids found in cheese for example, are lactic, acetic, and propionic acids. Likewise, the microorganisms involved in cheese manufacture and ripening are either mesophilic or thermophilic having temperature optima of $\sim 30^{\circ} \mathrm{C}$ or $42^{\circ} \mathrm{C}$, respectively. The temperature at which cheese is ripened is a compromise between the need to promote ripening reactions and control growth of the desirable secondary flora, and the need to prevent the propagation of potential spoilage and pathogenic bacteria. Higher temperatures promote accelerated ripening (Folkertsma et al. 1996), but the changes to body and flavour are often detrimental.

The proteolytic activity of the lactococcal strain in milk was measured after $24 \mathrm{~h}$ of incubation using SDS-PAGE method, conditioned according to the Box-Wilson Central Composite Experimental Design (CCD). This study is essentially based on the using of a simple technique widely used in laboratories, whose main scope relates to the qualitative aspect (SDS-PAGE), and by coupling it to a subsequent image analysis using the free software ImageJ of NIH (USA); we erected it at a quantitative technique grade by minimizing during this transition its background noise.

This experimental way combined with that of the use of Box-Wilson Central Composite Experimental Design (CCD), allowed us to establish a methodological approach, to our knowledge not documented until now for this area of interest using the whole cells as source of proteolytic enzymes to optimize their activity in milk, by seeking the appropriate physicochemical conditions, interacting at the same time for a maximum activity of interest, the aim of which is a probable release of a set of acids amines and peptides of interest. This experimental approach is certainly characterized by a background noise who would may be not negligible, and by using this methodological approach, we have significantly reduced this background noise, justified by the obtained correlation coefficient $\left(R^{2}=0.937\right)$, which means that the model proposed for the proteolytic activity in milk by Lactococcus lactis LCL strain, is correct and fulfills the robustness criteria of a model.

The proteolytic activity (Equation (5), Table 2) was found to be affected by all the variables considered. In particular, the presence of the quadratic terms of $\mathrm{pH}$ and temperature (with negative signs) indicates the presence of a maximum of this physiological activity in relation to these variables. This is showed in Figure 2, which suggests that the maximum proteolysis was reached at an incubation temperature and $\mathrm{pH}$ neighboring of $30^{\circ} \mathrm{C}$ and 7 respectively. In this aspect, the optimum levels for maximum proteolytic activity recorded for the integral cells of Lactococcus lactis LCL strain, are in agreement to those described for the proteolytic enzymes of a large set of bacteria (Cao et al. 2019; Do Carmo et al. 2011; Griffiths and Tellez 2013; Liu et al. 2010), which who report an optimum $\mathrm{pH}$ around neutrality (6 to 7). The role of temperature at a same position of as $\mathrm{pH}$, should not be underestimated, it is a key factor influencing the proteolysis process in milk. In fact, this variable considerably influenced this activity displaying an optimum at the neighborhood of 28 at $32^{\circ} \mathrm{C}$. Several authors report that proteolysis in milk depends on temperature of incubation which scales about 25 to $40^{\circ} \mathrm{C}$; which is not in contradiction with the results we have obtained. Indeed, Gobbetti $\boldsymbol{e t}$ al. (1999) obtained a positive effect of the combined action of temperature with $\mathrm{pH}$ on proteolytic activity, registered in the neighborhood of neutrality at $\mathrm{pH} 7.5$ and at $37{ }^{\circ} \mathrm{C}$. These observations consolidate the results, which we recorded in this work. By using central composite design and response surface method (RSM), we could able to optimize the proteolytic activity of Lactococcus lactis LCL strain by determining the area of the maximal response at the maximal point of the model. This area is located close to the central point, predicting a maximal response at $42.67 \%$ proteolysis rate, represented in desirability chart (Figure 3 ).

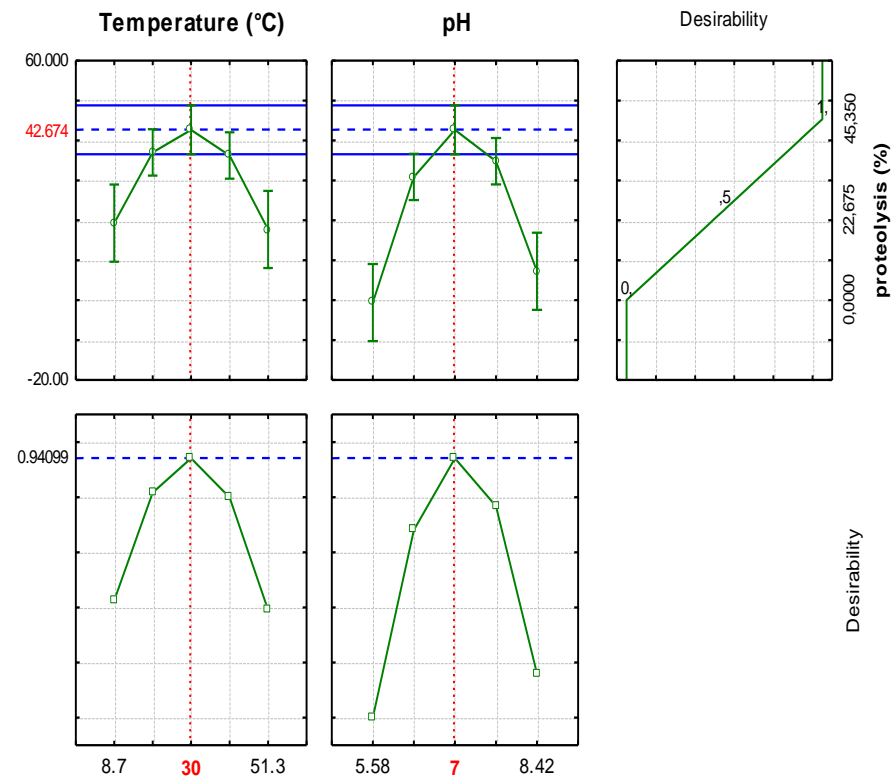

Figure 3 Desirability charts of variables for maximum response (Proteolytic activity) of Lactococcus lactis LCL strain

To confirm the model's adequacy for predicting the maximum proteolysis rate (response), we carried out a new three additional experiments using the optimum predicted levels. The mean value of proteolysis rate obtained is $43.7 \pm 1.4 \%$, which represents an additional proof of the quality of this model, binding effectively the predicted results at those of experiments approving its validity.

\section{CONCLUSION}

The Response Surface Methodology (RSM) based on Central Composite Design (CCD) was used to evaluate and to optimize the effect of Temperature and $\mathrm{pH}$ on the proteolytic activity of Lactococcus lactis LCL strain in milk. It was found that this activity increases in the system with the increase of the quadratic terms of the model, $\mathrm{X}_{1}$ (Temperature) and $\mathrm{X}_{2}(\mathrm{pH})$, affected at negatives coefficients. The combination of RSM based on CCD proved to be a powerful tool in the optimization of the proteolysis in milk. The optimization of the analyzed response demonstrates that the best result of proteolysis rate was around of $43.7 \pm 1.4 \%$, obtained at $30^{\circ} \mathrm{C}$ and $\mathrm{pH}$ 7. Results were in good agreement with the ones predicted by the model, displaying a coefficient of determination $\left(R^{2}\right)$ of 0,937 .

\section{REFERENCES}

Bhat, Z. F., \& Bhat, H. I. N. A. (2011). Milk and dairy products as functional foods: a review. International Journal of Dairy Science, 6(1), 1-12. https://doi.org/10.3923/ijds.2011.1.12

Box, G.E.P., \& Wilson, K. (1951). On the Experimental Attainment of Optimum Conditions. Journal of the Royal Statistical Society. Series B (Methodological), 13(1), 1-45. Retrieved August 2, 2021, from http://www.jstor.org/stable/2983966 Box, G.E.P., Draper, N.R. (1987). Empirical Model-Building and Response Surfaces. John Wiley \& Sons, New York

Cao C-C, Feng M-Q, Sun J, Xu X-L, Zhou G-H (2019) Screening of lactic acid bacteria with high protease activity from fermented sausages and antioxidant activity assessment of its fermented sausages CyTA. Journal of Food 17:347-354. https://doi.org/10.1080/19476337.2019.1583687

Casaburi, A., Di Martino, V., Ferranti, P., Picariello, L., \& Villani, F. (2016). Technological properties and bacteriocins production by Lactobacillus curvatus $54 \mathrm{M} 16$ and its use as starter culture for fermented sausage manufacture. Food Control, 59, 31-45. https://doi.org/10.1016/j.foodcont.2015.05.016

Christensen, J.E., Dudley, E.G., Pederson, J.A., Steele, J.L. (1999). Peptidases and amino acid catabolism in lactic acid bacteria. Antonie Van Leeuwenhoek, 76:217246. https://doi.org/10.1023/A:1002001919720

Do Carmo, A., da Silva, D., De Oliveira, M., Borges, A., De Carvalho, A., \& De Moraes, C. (2011). Genes involved in protein metabolism of the probiotic lactic acid bacterium Lactobacillus delbrueckii UFV H2b20. Beneficial microbes, 2(3), 209-220. https://doi.org/10.3920/BM2011.0025 
Donkor, O. N., Henriksson, A., Vasiljevic, T., \& Shah, N. P. (2007). Proteolytic activity of dairy lactic acid bacteria and probiotics as determinant of growth and in vitro angiotensin-converting enzyme inhibitory activity in fermented milk. Le Lait, 87(1), 21-38. https://doi.org/10.1051/lait:2006023

Fitzgerald, R. J., \& Murray, B. A. (2006). Bioactive peptides and lactic fermentations. International Journal of Dairy Technology, 59(2), 118-125. https://doi.org/10.1111/j.1471-0307.2006.00250.x

Folkertsma, B., Fox, P. F., \& McSweeney, P. L. H. (1996). Accelerated ripening of Cheddar cheese at elevated temperatures. International Dairy Journal, 6(1112), 1117-1134. https://doi.org/10.1016/0958-6946(95)00066-6

Francesc, T., Julia, G.M. (2014). Using central composite experimental design to optimize the degradation of real dye wastewater by Fenton and photo-Fenton $\begin{array}{cccc}\text { reactions. Dyes } & \text { Pigment, } & 100: 184-189 .\end{array}$ https://doi.org/10.1016/j.dyepig.2013.09.004

Frece, J., Kos, B., Svetec, I. K., Zgaga, Z., Beganović, J., Leboš, A., \& Šušković, J. (2009). Synbiotic effect of Lactobacillus helveticus M92 and prebiotics on the intestinal microflora and immune system of mice. Journal of Dairy Research, 76(1), 98-104. https://doi.org/10.1017/S0022029908003737

Ghadge, SV, Raheman, H (2006) Process optimization for biodiesel production from mahua (Madhuca indica) oil using response surface methodology. Bioresour. Technol., 97:379-384. https://doi.org/10.1016/j.biortech.2005.03.014

Gobbetti, M., Lanciotti, R., De Angelis, M., Rosaria Corbo, M., Massini, R., Fox, P.F. (1999). Study of the effects of temperature, $\mathrm{pH}, \mathrm{NaCl}$, and aw on the proteolytic and lipolytic activities of cheese-related lactic acid bacteria by quadratic response surface methodology. Enzyme and Microbial Technology, 25:795-809. https://doi.org/10.1016/S0141-0229(99)00110-6

Gobbetti, M., Minervini, F., \& Rizzello, C. G. (2004). Angiotensin I-convertingenzyme-inhibitory and antimicrobial bioactive peptides. International Journal of Dairy Technology, 57(2-3), 173-188. https://doi.org/10.1111/j.14710307.2004.00139.x

González, L., Sacristán, N., Arenas, R., Fresno, J. M., \& Tornadijo, M. E. (2010). Enzymatic activity of lactic acid bacteria (with antimicrobial properties) isolated from a traditional Spanish cheese. Food microbiology, 27(5), 592-597. https://doi.org/10.1016/j.fm.2010.01.004

Goupy, J. (1988). La méthode des plans d'expériences: optimisation du choix des essais et de l'interprétation des résultats (Vol. 29). Paris: Dunod.

Griffiths, M. W., \& Tellez, A. M. (2013). Lactobacillus helveticus: the proteolytic $\begin{array}{lllll}\text { system. Frontiers in Microbiology, } 4, & 30 .\end{array}$ https://doi.org/10.3389/fmicb.2013.00030

Hassaine, O., Zadi-Karam, H., Karam, N-E. (2007). Technologically important properties of lactic acid bacteria isolated from raw milk of three breeds of Algerian dromedary (Camelus dromedarius). Afr. J. Biotechnol. 6:1720-1727. https://doi.org/10.5897/AJB2007.000-2251

Hayes, M., Stanton, C., Fitzgerald, G. F., \& Ross, R. P. (2007). Putting microbes to work: dairy fermentation, cell factories and bioactive peptides. Part II: bioactive peptide functions. Biotechnology Journal: Healthcare Nutrition Technology, 2(4), 435-449. https://doi.org/10.1002/biot.200700045

Hebert, E. M., Mamone, G., Picariello, G., Raya, R. R., Savoy, G., Ferranti, P., \& Addeo, F. (2008). Characterization of the pattern of $\alpha$ s1-and $\beta$-casein breakdown and release of a bioactive peptide by a cell envelope proteinase from Lactobacillus delbrueckii subsp. lactis CRL 581. Applied and Environmental Microbiology, 74(12), 3682-3689. https://doi.org/10.1128/AEM.00247-08

Hebert, E. M., Raya, R. R., \& De Giori, G. S. (2000). Nutritional requirements and nitrogen-dependent regulation of proteinase activity of Lactobacillus helveticus CRL 1062. Applied and Environmental Microbiology, 66(12), 5316-5321. https://doi.org/10.1128/AEM.66.12.5316-5321.2000

Hebert, E. M., Saavedra, L., \& Ferranti, P. (2010). Bioactive Peptides Derived from Casein and Whey Proteins. In: Biotechnology of Lactic Acid Bacteria. F. Mozzi, R.R. Raya, G.M. Vignolo, Ames: Wiley-Blackwell. pp 233-249. https://doi.org/10.1002/9780813820866.ch13

Hugenholtz, J, Kleerebezem, M (1999) Metabolic engineering of lactic acid bacteria: overview of the approaches and results of pathway rerouting involved in food fermentations. Curr. Opin. Biotechnol., 10:492-497. https://doi.org/10.1016/S0958-1669(99)00016-6

Konings, W. N., Kok, J., Kuipers, O. P., \& Poolman, B. (2000). Lactic acid bacteria: the bugs of the new millennium. Current opinion in microbiology, 3(3), 276-282.https://doi.org/10.1016/S1369-5274(00)00089-8

Korhonen, H., \& Pihlanto, A. (2006). Bioactive peptides: production and functionality. International dairy journal, 16(9), 945-960. https://doi.org/10.1016/j.idairyj.2005.10.012

Laemmli, U.K. (1970). Cleavage of structural proteins during the assembly of the head of bacteriophage T4. Nature 227:680-685. https://doi.org/10.1038/227680a0
Lawa, J., \& Haandrikmat, A. (1997). Proteolytic enzymes of lactic acid bacteria. International Dairy Journal 7:1-11 https://doi.org/10.1016/0958-6946(95)000739

Liu, M., Bayjanov, J. R., Renckens, B., Nauta, A., \& Siezen, R. J. (2010). The proteolytic system of lactic acid bacteria revisited: a genomic comparison. BMC genomics, 11(1), 1-15. https://doi.org/10.1186/1471-2164-11-36

Liu, R., Xing, L., Fu, Q., Zhou, G. H., \& Zhang, W. G. (2016). A review of antioxidant peptides derived from meat muscle and by-products. Antioxidants, 5(3), 32. https://doi.org/10.3390/antiox5030032

Mangayil, R., Aho, T., Karp, M., \& Santala, V. (2015). Improved bioconversion of crude glycerol to hydrogen by statistical optimization of media components. Renewable Energy, 75, 583-589. https://doi.org/10.1016/j.renene.2014.10.051

Matar, C., LeBlanc, J. G., Martin, L., \& Perdigón, G. (2003). Biologically active peptides released in fermented milk: role and functions. In: Handbook of fermented functional foods, vol 177. 1st Edn., E.R.Farnworth (Boca Raton,FL: CRCPress), p 201

Mills, S., Ross, R. P., Hill, C., Fitzgerald, G. F., \& Stanton, C. (2011). Milk intelligence: Mining milk for bioactive substances associated with human health. International dairy journal, 21(6), 377-401. https://doi.org/10.1016/j.idairyj.2010.12.011

Moraes, P. M., Perin, L. M., Ortolani, M. B. T., Yamazi, A. K., Viçosa, G. N., \& Nero, L. A. (2010). Protocols for the isolation and detection of lactic acid bacteria with bacteriocinogenic potential. LWT-Food Science and Technology, 43(9), 13201324. https://doi.org/10.1016/j.lwt.2010.05.005

Ni, K., Wang, Y., Li, D., Cai, Y., \& Pang, H. (2015). Characterization, identification and application of lactic acid bacteria isolated from forage paddy rice silage. PloS one, 10(3), e0121967. https://doi.org/10.1371/journal.pone.0121967 Paul, M., \& Somkuti, G. A. (2009). Degradation of milk-based bioactive peptides by yogurt fermentation bacteria. Letters in applied microbiology, 49(3), 345-350. https://doi.org/10.1111/j.1472-765X.2009.02676.x

Paul, M., \& Somkuti, G. A. (2010). Hydrolytic breakdown of lactoferricin by lactic acid bacteria. Journal of Industrial Microbiology and Biotechnology, 37(2), 173178. https://doi.org/10.1007/s10295-009-0660-6

Perez, R. H., Zendo, T., \& Sonomoto, K. (2014). Novel bacteriocins from lactic acid bacteria (LAB): various structures and applications. Microbial cell factories, 13(1), 1-13. https://doi.org/10.1186/1475-2859-13-S1-S3

Rao, Y. K., Lu, S. C., Liu, B. L., \& Tzeng, Y. M. (2006). Enhanced production of an extracellular protease from Beauveria bassiana by optimization of cultivation processes. Biochemical Engineering Journal, 28(1), 57-66. https://doi.org/10.1016/j.bej.2005.09.005

Ras El Gherab, F. Z., Hassaine, O., Zadi-Karam, H., \& Karam, N. E. (2019). Statistical optimization for the development of a culture medium based on the juice of waste-dates for growth of Lactococcus lactis LCL strain by using the PlackettBurman and response surface methodology. Waste and Biomass Valorization, 10(10), 2943-2957. https://doi.org/10.1007/s12649-018-0283-0

Rodríguez-Serrano, G. M., García-Garibay, M., Cruz-Guerrero, A. E., GómezRuiz, L., Ayala-Nino, A., Castaneda-Ovando, A., \& Gonzalez-Olivares, L. G. (2018). Proteolytic system of Streptococcus thermophilus. Journal of microbiology and biotechnology, 28(10), 1581-1588. https://doi.org/10.4014/jmb.1807.07017

Sadat-Mekmene, L., Genay, M., Atlan, D., Lortal, S., \& Gagnaire, V. (2011). Original features of cell-envelope proteinases of Lactobacillus helveticus. A review. International Journal of Food Microbiology, 146(1), 1-13. https://doi.org/10.1016/j.ijfoodmicro.2011.01.039

Savijoki, K., Ingmer, H., \& Varmanen, P. (2006). Proteolytic systems of lactic acid bacteria. Applied microbiology and biotechnology, 71(4), 394-406. https://doi.org/10.1007/s00253-006-0427-1

Settanni, L., \& Moschetti, G. (2010). Non-starter lactic acid bacteria used to improve cheese quality and provide health benefits. Food microbiology, 27(6), 691-697. https://doi.org/10.1016/j.fm.2010.05.023

Shihata, A., \& Shah, N. P. (2000). Proteolytic profiles of yogurt and probiotic bacteria. International Dairy Journal, 10(5-6), 401-408. https://doi.org/10.1016/S0958-6946(00)00072-8

Silva, S. V., \& Malcata, F. X. (2005). Caseins as source of bioactive peptides. $\begin{array}{llll}\text { International dairy journal, } & 15(1), & 1-15 .\end{array}$ https://doi.org/10.1016/j.idairyj.2004.04.009

Smit, G., Smit, B.A., Engels, W.J. (2005). Flavour formation by lactic acid bacteria and biochemical flavour profiling of cheese products FEMS Microbiol Rev 29:591610. https://doi.org/10.1016/j.fmrre.2005.04.002

Somkuti, G. A., \& Paul, M. (2010). Enzymatic fragmentation of the antimicrobial peptides casocidin and isracidin by Streptococcus thermophilus and Lactobacillus delbrueckii ssp. bulgaricus. Applied microbiology and biotechnology, 87(1), 235242. https://doi.org/10.1007/s00253-009-2433-6 
Steele, J, Broadbent, J, Kok, J (2013) Perspectives on the contribution of lactic acid bacteria to cheese flavor development. Curr Opin Biotechnol 24:135-141. https://doi.org/10.1016/j.copbio.2012.12.001

Tang, X. J., He, G. Q., Chen, Q. H., Zhang, X. Y., \& Ali, M. A. (2004). Medium optimization for the production of thermal stable $\beta$-glucanase by Bacillus subtilis ZJF-1A5 using response surface methodology. Bioresource Technology, 93(2), 175-181. https://doi.org/10.1016/j.biortech.2003.10.013

Terzaghi, B.E., Sandine, W.E. (1975). Improved medium for lactic streptococci and their bacteriophages. Appl Microbiol 29:807-813. https://doi.org/10.1128/am.29.6.807-813.1975

Tripathi, P., Kumar, A., Srivastava, V. (2009). Optimization of an azo dye batch adsorption parameters using Box-Behnken design. Desalination 249:1273-1279. https://doi.org/10.1016/j.desal.2009.03.010

Tsakalidou, E., Anastasiou, R., Vandenberghe, I., van Beeumen, J., Kalantzopoulos, G. (1999). Cell-wall-bound proteinase of Lactobacillus delbrueckii subsp. lactis ACA-DC 178: characterization and specificity for betacasein. Appl Environ Microbiol 65:2035-2040. https://doi.org/10.1128/AEM.65.5.2035-2040.1999

Tulini, F. L., Hymery, N., Haertlé, T., Le Blay, G., \& De Martinis, E. C. (2016). Screening for antimicrobial and proteolytic activities of lactic acid bacteria isolated from cow, buffalo and goat milk and cheeses marketed in the southeast region of Brazil. Journal of Dairy Research, 83(1), 115-124. https://doi.org/10.1017/S0022029915000606

Vinderola, G., Matar, C., \& Perdigón, G. (2007). Milk fermented by Lactobacillus helveticus R389 and its non-bacterial fraction confer enhanced protection against Salmonella enteritidis serovar Typhimurium infection in mice. Immunobiology, 212(2), 107-118. https://doi.org/10.1016/j.imbio.2006.09.003

Wakai, T., \& Yamamoto, N. (2012). Antihypertensive peptides specific to Lactobacillus helveticus fermented milk. Biotechnology-Molecular Studies and Novel Applications for Improved Quality of Human Life, Biochemistry, Genetics and Molecular Biology, ed. RH Sammour (Rijeka: InTech), 159-172.

Xing, L., Ge, Q., Jiang, D., Gao, X., Liu, R., Cao, S., ... \& Zhang, W. (2018). Caco2 cell-based electrochemical biosensor for evaluating the antioxidant capacity of Asp-Leu-Glu-Glu isolated from dry-cured Xuanwei ham. Biosensors and Bioelectronics, 105, 81-89. https://doi.org/10.1016/j.bios.2018.01.020

Zhang, J., Zhou, J., Liu, J., Chen, K., Liu, L., Chen, J. (2011). Development of chemically defined media supporting high cell density growth of Ketogulonicigenium vulgare and Bacillus megaterium. Bioresour Technol 102:4807-4814. https://doi.org/10.1016/j.biortech.2010.10.124 